\title{
СИНТЕЗ И АНТИОРТОПОКСВИРУСНАЯ АКТИВНОСТЬ ПРОИЗВОДНЫХ БИЦИКЛИЧЕСКИХ ТЕРПЕНОИДОВ
}

\author{
А.С. Соколова ${ }^{1}$, С.О. Куранов', К.С. Ковалева', О.И. Яровая', \\ Н.И. Бормотов ${ }^{2}$, Л.Н. Шишкина' ${ }^{2}$ Н.Ф. Салахутдинов ${ }^{1}$ \\ ${ }^{1}$ Новосибирский институт органической химии им. Н.Н. Ворожцова СО РАН, \\ 630090, Россия, Новосибирск, Академика Лаврентьева, д.9. \\ ${ }^{2}$ ФБУН ГНЦ ВБ «Вектор» Роспотребнадзора, \\ 630559, Россия, Новосибирская область, р.п. Кольцово.
}

DOI: 10.19163/MedChemRussia2021-2021-213

E-mail: asokolova@nioch.nsc.ru

Ортопоксвирусы, принадлежащие к семейству Poxviridae, содержат более 10 видов вирусов, включая вирусы натуральной оспы, осповакцины, оспы коров, оспы обезьян, эктромелии и др. Вспышки натуральной оспы, происходили в истории человечества в течение тысяч лет, но с 1980 года после успешной программы вакцинации, проводимой Всемирной организации здравоохранения, данное заболевание было ликвидировано на планете. Однако нет никаких гарантий, что эта болезнь не возникнет в будущем, поскольку ортопоксвирусы способны выживать в течение десятилетий при низких температурах в местах захоронений умерших от оспы.

В рамках данной работы, на основе коммерчески доступных монотерпеноидов, таких как (+)-камфора и (-)-фенхон были синтезированы производные, включающие бициклический остов, ароматический фрагмент и азотсодержащую функциональную группу между ними (рисунок 1).<smiles>[R]C(=O)N/N=C1\C2CC3CC(C)(C2)CC13C</smiles><smiles>[R]C(=O)NC1CC2CCC1(C)C2(C)C</smiles><smiles>[R]C(=O)NN=C1C2(C)CCC(CC2)C1(C)C</smiles><smiles>[R]C(=O)NC1C2(C)CCC(CC2)C1(C)C</smiles>

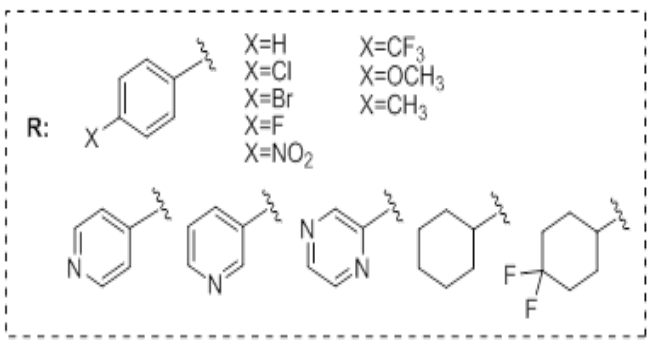

Puc. 1.

Была исследована противовирусная активность синтезированных агентов в отношении вируса осповакцины, вируса эктромелии и вируса оспы коров. Наибольшую вирусингибирующую активность проявили производные, включающие в пара-положение нитро группу или атом галогена.

Работа выполнена при финансовой поддержке Российского Фонда Фундаментальных исследований (N 20-33-70067). 